\title{
The Väinö Kannisto Fund Award for Merit in 1998-2002
}

STINA FÅGEL, M.A. (Educ.), Research Secretary

The Population Research Institute,

The Family Federation of Finland

In 1997 Dr. Väinö Kannisto received the Prix de la Longevité -prize from the French IPSEN Foundation in recognition of his distinguished career in the field of demography. He donated the prize to the Population Research Institute of the Family Federation of Finland as the founding capital for the Väinö Kannisto Fund, which bears his name. The Fund bestows an annual award in recognition of merit for the best demographic thesis in the field of mortality and health research.

The prize is awarded for a master's, licentiate or doctoral thesis made in Finland in Finnish or in some other major language, primarily English. The recipient of the award is chosen by the Fund's Administrative Committee.

The size of the award has varied from 1,330 to 1,700 Euros. All of the studies that have thus far been awarded the prize have been doctoral dissertations. The first merit award was bestowed in 1998 on Pekka Jousilahti, M.D., for his study entitled The Role of Risk Factors and Risk Factor Changes in Coronary Heart Disease and in Coronary Heart Disease Trends in Eastern and Southwestern Finland. In 1999 the merit award was given to Kristiina Manderbacka, D.Soc.Sc., for her study Questions on Survey Questions on Health.

In 2000 the prize was awarded to Pia Mäkelä, D.Soc.Sc., for her research entitled Alcohol-Related Deaths. Prevalence and Relation to Gender and Socioeconomic Status and in 2001 the recipient of the award was Tiina Laatikainen, Lic.Med., for her study Cardiovascular Risk in the Republic of Karelia, Russia: Comparison of Major Risk Factors with North Karelia, Finland.

In 2002 Leena Rask-Nissilä, M.D., was given the award for her study Neurological Development and Serum Lipids and Lipoproteins in a Coronary Heart Disease Prevention Trial in Childhood. The STRIP Project. 
The award can be deferred in any given year if the Fund has received no applications of a sufficiently high standard that year in its field. The funds thus accruing can be used in a later year to award two prizes in full to applicants fulfilling the requirements. The decision has also been made that in the future the announcement for applications for the award would state that the award is to be given for a doctoral dissertation.

In 2002 the winner of the award was announced at the 28th Postgraduate and Further Education Seminar arranged by the Finnish Demographic Society and the Department of Sociology, University of Helsinki. The seminar was arranged together with the Estonian Interuniversity Population Research Centre on October 3-4, 2002 in Tallinn. In the future the winner of the award will be announced at this population seminar that is arranged every autumn.

Stina Fågel, M.A. (Educ.)

Secretary of the Väinö Kannisto Fund Administrative Committee tel +358 (0)922805120 stina.fagel@,vaestoliitto.fi 